\title{
Introduction: a special issue in honoring Janos Kornai
}

\author{
Mehrdad Vahabi ${ }^{1}$
}

Accepted: 5 February 2021 / Published online: 21 March 2021

(c) The Author(s), under exclusive licence to Springer Science+Business Media, LLC part of Springer Nature 2021

\begin{abstract}
Janos Kornai is one of the leading economists of the twentieth century. Unfortunately, his interdisciplinary, systemic approach and the Austro-Hungarian convergence on the socialist calculation debate are not explored sufficiently by public choice scholars or by political scientists and economists more generally. The essays published herein try to fill the gaps. In doing so, we start by asking: what is the specific contribution of the eminent economist Janos Kornai to our discipline? The contributions demonstrate that no unique answer to that question is possible. However, despite the diversity of responses, they all converge on one point: Kornai contributes to our understanding of the consequences of an allegedly 'omnipresent' state.
\end{abstract}

Keywords Austro-hungarian convergence $\cdot$ Contradictions and dilemmas · Disequilibrium school $\cdot$ Marx $\cdot$ Soft budget constraints $\cdot$ System paradigm

JEL Classifications B31 $\cdot$ B51 $\cdot$ B52 $\cdot$ B53 $\cdot$ D50 $\cdot$ E11 $\cdot$ E14 $\cdot$ H82 $\cdot$ P2 $\cdot$ P3 $\cdot$ P4 · P5

\section{Introduction: honoring Janos Kornai}

Janos Kornai is one of the leading economists of the twentieth century. Unfortunately, his interdisciplinary, systemic approach and the Austro-Hungarian convergence on the socialist calculation debate are not explored sufficiently by public choice scholars or by political scientists and economists more generally. Leeson (2008, p. 3) already has underlined that "the close connection between the substance and development of several of Kornai's ideas and those of Mises and Hayek are virtually unnoted." "The present special issue tries to fill the gaps. In doing so, we start by asking: What is the specific contribution of the eminent economist Janos Kornai to our discipline?

The present special issue demonstrates that no unique answer to that question is possible. However, despite the diversity of responses, they all converge on one point: Kornai contributes to our understanding of the consequences of an allegedly 'omnipresent' state.

1 Socialists and Marxists also need to revisit Marx in the light of the experiences of actual socialist systems; see, e.g., 'Marx after Kornai' (Sen 2020).

Mehrdad Vahabi

mehrdad.vahabi@wanadoo.fr

1 CEPN, University of Sorbonne Paris Nord, Paris, France 
Historically speaking, such a politico-economic regime appeared in consequence of the last century's two world wars, in which whole societies were mobilized to serve the state (Vahabi et al. 2020). War socialism was the basis of what later transformed into Soviettype economies, essentially total mobilization of society's resources during peacetime. As Lange (1958, p. 3) suggested,

I think that, essentially, it [socialism] can be described as a sui-generis war economy. Such methods of war economy are not peculiar to socialism because they are also used in capitalist countries in war time. They were developed in the first and second World War. In capitalist countries similar methods were used during the war, namely, concentration of all resources on one basic purpose, which was the production of war material.

Kornai (1992, pp. 11-12) described the socialist system as state control of the economy under the undivided power of the Communist Party. Other common labels were "actually existing socialism", "centrally administered economy", "centrally planned economy", "command economy", "state socialism", and "Soviet-type system". Many socialists do not consider that type of regime to be 'true socialism' as conceived by Karl Marx, but an ideal model of socialism never has been at the center of Kornai's investigations. His main interest always has been the analysis of reality as it is and as it evolves. Kornai focuses on how socialism worked in practice.

For Kornai, a social scientist should in the first place be a good observer. His Ph.D. thesis (Kornai 1957/1994) on Overcentralization in Economic Administration (translated into English a year after its publication) provides a salient application of his positive analytical tools. The book offered a systematic analysis of the Hungarian socialist enterprise in light industry (see Gregory 2019) instead of the more common doctrinal references to the "economic laws or tendencies" of an ideal type of socialist system. Over more than half a century, Kornai documented different aspects of the socialist system and its dynamics: its over-centralization, bureaucratic mode of coordination, sellers' markets, semi-passivity of monetary policy, soft budget constraints and its related nominal and real inefficiencies (known as the Kornai effect), investment shortfalls, slack and urgency in fulfilling topdown plans. All of those concepts revealed the normal state of a socialist system as a shortage economy (Kornai 1980). Kornai contrasts a shortage economy to a surplus economy, depicting the latter as the normal state of capitalist system (Kornai 2013). In his eyes, economic systems are characterized by specific and chronic disequilibria (Kornai 1971). In that sense, his recommended methodology in comparative analysis of economic systems is to avoid Harold Demsetz's (1969) 'Nirvana fallacy', i.e., comparisons of the reality of one economic system with an ideal type of another.

"Marx after Kornai" is the title of Amartya Sen's (2020) excellent contribution to this special issue. The title in itself goes beyond a paper: it is a call for a completely new research program involving rereading Marx in light of Kornai's positive analysis of the whole socialist experience in Soviet-type economies. Sen aptly chooses Marx to understand Kornai better. Kornai may or may not agree what Sen sees as his commonalities and diverging points with Marx (see the exchange between Kornai and Sen on Marx in this issue), but Kornai has named Marx more than once as one of the four thinkers who influenced him the most. The other three were Hayek, Schumpeter and Tinbergen (Kornai 1972, p. ix). Later on, he replaced Tinbergen with Keynes as the fourth influential author on his own work (see Kornai 1992, p. xx, 2009, p. 982).

It is hard to validate Keynes's influence on Kornai. Although Kornai is one of the proponents of a disequilibrium school depicting capitalist system as a 'surplus economy', he 
does not accept the Keynesian notion of 'aggregate demand' (see Andreff 2020) and rejects shortage as a form of 'repressed inflation' (Kornai 1980, 1985b). In fact, Kornai's filial relationship with the disequilibrium school is based on his adherence to the Marshallian equilibrium concept, which is consistent with a narrow range of disequilibria around a normal value (see Vahabi 1998, 2018). But Kornai's version of disequilibrium is not related directly to the Keynesian theory of aggregate demand, explaining why all other strands of the disequilibrium school diverge from Kornai (see Laffont 1985). Furthermore, Kornai's analysis of chronic unemployment in capitalist labor markets also is inspired primarily by Marx's 'reserve army of labor' (Kornai 1980), and not by Keynes's distinction between voluntary and involuntary unemployment.

The influence of Schumpeter on Kornai's theoretical framework is not extensive. It is clear that Kornai (2013) has mobilized Schumpeterian 'creative destruction' to underline the importance of innovation in capitalist systems and its absence from socialist systems. His line of argument has been developed by Huang and Xu (1999a, b), Xu et al. (2020). A few references to Schumpeter's theory of entrepreneurial activities and their search for super-profits (conflated with rent seeking) in his recent works (Kornai 2016b) are not sufficient to grasp how Schumpeter influenced Kornai's original theorizing. It is noteworthy that Kornai (2009, p. 981) traces back the origins of creative destruction to Marx and Engels rather than to Schumpeter.

The influence of the last two monumental figures, namely Marx and Hayek, on Kornai's thought is undeniable. Marx, however, has an even more significant place in Kornai's personal and professional career: "If forced to name those who have influenced me most, I mention the names of Schumpeter, Keynes, and Hayek, but first on the list comes the name of Karl Marx" (Kornai 2009, p. 892). Kornai's relationship with Marx not only was academic or analytical, but a matter of faith. He became a Marxist not because of his vast knowledge of Marx's work, but because of his position as a Jew during the Second World War, when his father and brother were assassinated by German Fascists (Kornai 2006). He broke with Marx on the basis of ethical considerations, particularly when he became aware in 1956 that senior colleagues and old Communists had been arrested and tortured without committing any crime. Kornai's (2020) own contribution to this special issue titled "1956 in Hungary: as I saw it then and as I see it now" provides a historical document about that revolution explaining the reasons Kornai abandoned Marxism and the Hungarian Communist Party. Loss of faith explains in part Kornai's anti-Marxist position. However, the theoretical argument lying behind that stance is what Kornai calls Marx's 'intellectual responsibility' for the historical reality of the socialist system.

According to Kornai, the Soviet Union and other communist countries implemented two basic tenets of Marx's line of thinking, namely the transformation of private property into state property and the replacement of markets by central planning, bureaucratic coordination and the command economy. ${ }^{2}$ A third explanation is Marx's treating 'formal', 'bourgeois' democracy, parliamentarianism, and legality as 'illusory'. Based on those three considerations, Kornai argues that Marx bears 'intellectual responsibility’ for realized socialist

\footnotetext{
${ }^{2}$ Lange (1958, p. 2) agrees that the two fundamental components of any socialist revolution are the predominance of state property and central planning: "It seems to me that first, the very process of the social revolution which liquidates one social system and establishes another requires centralised disposal of resources by the new revolutionary State, and consequently centralised management and planning. This holds, in my opinion, for any socialist revolution."
} 
systems. Despite Kornai's anti-Marxist position, he acknowledges Marx's strong influence on his thought.

The first major link between Kornai and Marx is the 'system paradigm': the view that does not isolate sections or coherent parts of society, namely the political, cultural and economic spheres, but focuses on the whole that emerges from the parts. That perspective has two implications for Kornai. First, he is a fervent advocate of interdisciplinary studies; he himself acts simultaneously as an economist, a political scientist, a sociologist, and a historian. In brief, he follows Marx as a comprehensive social scientist. The second implication is Marx's influence on Kornai's concept of 'great systems' (Vahabi 2018). Interpreting Marx, Kornai (1992) set out to clarify what is meant by a 'great' system. He summed up three major characteristics of any economic system: (1) political structure and related dominant political ideology; (2) property relationships; and (3) coordination mechanisms (the relative weights of market, bureaucratic, ethical, or other types of coordination mechanisms). In his recent paper on the system paradigm, Kornai (2016a, p. 549) acknowledges that what he calls a 'great system' is related to the neo-Marxist concept of social formation. He considers socialism to be a system or a constellation of the parts of an organic order with specific self-reproducing regularities. System coherence does not exclude disequilibrium, contradictions and dilemmas.

The second major influence of Marx on Kornai's 'system paradigm' is 'contradictions and dilemmas' (Kornai 1985a). According to Kornai, any economic system contains specific conflicts or contradictions. For example, the same process that guarantees full employment generates both shortages of labor and unemployment. The same mechanisms that ensure rapid economic growth in the short run ('rush' in Kornai's 1972 terminology) will lead in the long term to shortages, frictions in adjusting labor supply to demand and, ultimately, impediments to growth. Those contradictions or conflicts do not arise from the faults of a particular manager, bad planning or a bad style of work: "The cause lies deeper than those, in the power structure of society and the form of ownership and institutional system in it" (Kornai 1985a, p. 3).

'Dilemmas' refer to the absence of a unique 'optimal solution' to contradictions. If you choose one thing, it will be good from a certain point of view, but from another it will be bad. If reality involves contradictions, a decision-maker inevitably must face dilemma. Kornai grasped much better the irreformability of the socialist system in the light of system-specific contradictions and dilemmas. In a second book on 'contradictions and dilemmas' (Kornai 1990a), Kornai revisited the Hungarian reform process in the 1980s without sharing the naïve vision of reformers who wished to combine the best of socialist 'equity' with the best of capitalist 'efficiency', as if institutional reform is like shopping in a supermarket and choosing the best items from each shelf. Market socialism built on a combination of preponderant state property and market coordination, which was emblematic of naïve reformers' wishful thinking (Kornai 1986).

As I have argued (Vahabi 2019), Kornai's intellectual contribution was to formulate a revolutionary discourse emphasizing the sterility of socialist half-measures, cosmetic changes, and reform packages. His conclusion rested on two foundations: (1) the unity or what Kornai calls the 'coherence' of socialism as a system, and (2) rejection of market socialism as hopelessly confused. Accordingly, reforms would at best introduce inconsistencies, without solving socialism's chronic problems. Moreover, the inconsistences of the half-measures would erode socialist systems, inevitably leading to revolution.

Kornai was inspired by Marx in formulating the first underlining tenet of a revolutionary perspective for transforming the socialist system and by Hayek regarding the second one. We will review Kornai's relationship with Hayek below. But to summarize Kornai's 
complex relationships with Marx, it can be said at the cost of simplification that despite his anti-Marxism Kornai paradoxically continued to be a 'Marxist' in calling for the transformation of the socialist system.

Hayek influenced Kornai's thought in two major ways: understanding (1) market processes by critiquing market socialism and (2) the relationship between the market process and private property. That is not to suggest that Kornai has become an Austrian economist or that he copied Hayek. He formulated original theses on both issues, but his convergence with Austrian economics is undeniable. Kornai cannot be pigeonholed into any school of thought. Borrowing Engles's ironical expression, Kornai (2009, p. 982) suggests that the elements of his thinking mingle in an 'eclectic beggar's soup'.

One of the major elements of that eclectic soup is the Austro-Hungarian convergence on the socialist calculation debate (Vahabi 1995). In fact, Kornai's concept of 'soft budget constraint' was a kind of 'rediscovery' of the Mises-Hayek position (Streissler 1991, p. 197) regarding the passivity of money under socialism and its inefficiency consequences, known as Kornai's 'double effects' (real and monetary inefficiencies) (Vahabi 2001, pp. 171-176). It was through a critical appraisal of market socialism that Kornai reproached the purely Hayekian vision of market process and sided with Mises-Hayek (see Andreff 2020; Boettke and Candela 2020; Vahabi 2019). Kornai (1971) had rejected Walrasian general equilibrium as the basic model of Lange's vision of market socialism. Interestingly, while mainstream economics never has accepted Kornai's anti-equilibrium, his concept of soft budget constraint mobilized by the World Bank, the IMF and many other international institutions was integrated partially by game theorists into models of asymmetric information and credible commitments (Kornai et al. 2003). Kornai's critical assessment of market socialism was not limited to Lange's interpretation. ${ }^{3}$ He broadened the scope of criticism to market socialism as a reform project in different countries based on a combination of preponderant state property and market coordination, especially in Hungary (the New Economic Mechanism implemented on January 1, 1968), Czechoslovakia (Ota Sik's 'socialism with human face'), Gorbatchev's Perestroika and Chinese market socialism.

The second convergence was on the issue of property rights, particularly the strong links between market coordination and private property. Kornai (1990b) formulated an 'affinity thesis', according to which the bureaucratic mode of coordination has a natural affinity for (strong linkage with) state property, while market coordination has a natural affinity for private property. By contrast, the linkage between 'market coordination' and state property is weak, meaning that one cannot rely on the market as a neutral instrument underpinning state property or socialism (see Mihályi and Szelényi 2020).

Comparing Marx's influence with Hayek's on Kornai thought, it seems that Kornai was influenced by the former on the need for a revolutionary perspective on transforming the

\footnotetext{
3 Kornai (1991) distinguishes three phases in the development of 'market socialism': (1) vision, (2) project and (3) blueprints of a reform policy. Lange's model was a vision never realized in practice and, according to Kornai, Lange himself never recommended its implementation. Market socialism as a 'project' was formulated by many theorists like Brus, Sik and Nove. But a project also is far from offering practical policy steps. Market socialism rarely was implemented in the form of 'blueprints of a reform policy'. The closest one was Hungary's New Economic Mechanism (NEM), introduced on January 1, 1968), although it was far from Lange's model. Kornai introduced a broader definition of market socialism as a combination of preponderant state property and market coordination (Kornai 1990b). According to that definition, he distinguished classical (Stalinist) socialist systems from reformed (or market) socialism (Kornai 1992). I follow Kornai's distinction without ignoring the fact that market socialism in practice is not an implementation of Lange's model.
} 
socialist system, while his vision of a capitalist system (notably the market process and private property) was inspired by Hayek.

Considering Kornai's original contributions as well as his two major sources of inspiration, Kornai's thought cannot be pigeonholed into mainstream economics. However, his eclectic soup fed a whole generation of Marxist and non-Marxist economists in Hungary and the Eastern bloc about the main ideas, methods and assumptions of modern general equilibrium theory (GET). Those economists learned about GET through Kornai's works. In that sense, Kornai largely served mainstream economics by forging a link between Eastern and Western economic thought. More recently, Kornai described his position in the following terms: "Nowadays, I like to characterize myself as having one foot in and one foot out of the mainstream" (Kornai 2006, p. 195). Although anti-equilibrium raises a direct challenge to mainstream economics, Kornai $(1971$, p. 4) is not wrong to say that he nevertheless had one foot in the orthodoxy: "I consider myself a mathematical economist; thus[,] my critical remarks come not from 'outside' but from'inside' the circle. These remarks, therefore, may be regarded in many cases as self-criticism as well as criticism. It is my conviction that the further progress of economic theory will depend, if not exclusively, at least significantly, on the advances made in the field of mathematical economics. It is in this area that I hope my work can make a contribution." Kornai's contribution is immense and both mainstream and critical approaches would need him to enrich the way they understand the economic world.

\section{A tour of the issue}

The articles contained in the special issue can be divided into two groups. The first group discusses Kornai's theoretical framework; the second examines applications and further developments of his contributions in two areas: (1) soft budget constraints and (2) political economy.

Before summarizing the articles briefly, the issue starts with a short report on the Hungarian revolution in 1956 by Janos Kornai. It is a historical document in which Kornai provides many details about the then-emerging Institute of Economics of the Hungarian Academy of Sciences, the role of daily newspaper Szabad Nép in the upheaval and, most interestingly, his own intellectual immaturity, which prevented him from offering an alternative economic system: "I was not ready to work out the economic policy of a government that had broken its ties with all forms of the communist system" (Kornai 2020). In fact, the paper casts light on the historical context in which naïve reformism emerged in the aftermath of 1956's events. We can understand better why critical economic thinkers were groping to define an alternative system by searching for alternative planning procedures (Kornai and Liptak 1965) to replace imperious planning during the 1956-1968 period.

After that personal testimony, the first group of articles includes five papers, which begin with Sen's "Marx after Kornai". There, Sen explores Kornai's political and professional relationship with Marx as an economist after the latter's break with Marxism in 1956. He particularly underlines Kornai's value system, particularly equity and freedom, and suggests that "some of Marx's own theses can be enriched interestingly by taking note of Kornai's later writings." Sen's paper opened an open discussion between Kornai and Sen that has been captured in a 'Commissioned editorial commentary: exchange between Janos Kornai and Amartya Sen on Karl Marx’ (2021, in this special issue). 
Vahabi's paper endeavors to capture Kornai's principal message. In his opinion, Kornai's intellectual contribution was to formulate a revolutionary discourse by demonstrating that dysfunctional properties of socialism are endemic, systemic and, hence, cannot be "reformed". Vahabi discusses Kornai's 'system paradigm', its application to socialism, and the distinction between revolution and reform from an institutionalist perspective. Reviewing Kornai's comparative analysis of 'great systems', Vahabi concedes the primacy of politics in war socialism during peacetimes. However, Vahabi questions the primacy of politics in capitalist systems, wherein economics rather than politics is supposed to have primacy.

Gregory's contribution examines in detail Kornai's first academic work, namely his $\mathrm{Ph} . \mathrm{D}$. thesis on Overcentralization in Economic Administration. The paper contextualizes Kornai's book by referring to the parallel research of the 1950s by American scholars, such as Joseph Berliner, David Granick, Gregory Grossman and Eugene Zaleski, who applied similar methods and arrived at similar conclusions. Reviewing Kornai's investigation into Hungary's light industry, Gregory argues that Kornai found little evidence of comprehensive planning. Instead, Kornai determined that the planning system consisted of quarterly gross output orders that readily could be manipulated by plant managers and had to be fulfilled at any price. Kornai's later introduction to the book in the 1990s is quoted by Gregory to show that Overcentralization already contained the seeds of Kornai's later key findings regarding the dysfunctionalities of socialist planning, namely, soft budget constraints and the shortage economy. Kornai's most important conclusion largely was overlooked throughout the socialist world: the planned economy could not be reformed by half-measures.

Andreff's paper provides a comprehensive analysis of Kornai's work on planning procedures and the disequilibrium school. He revisits Kornai's position concerning the feasibility of socialist planning (Lange versus Hayek), and underlines Kornai siding with Hayek, contending that without an actual market price system for conveying information to those who can use it beneficially, a socialist economy is impracticable. That conclusion was paradoxical considering that Kornai worked at the Computer Centre of the Hungarian Academy of Sciences in connection with the Planning Institute of the National Planning Office. There, he conceived an algorithm for decentralized two-level planning, i.e., the best improvement ever brought into Lange's model of market socialism. Cognizant of the actual dysfunctions of Hungarian central planning in terms of shortages, Kornai eventually theorized Economics of Shortage on the basis of disequilibrium modelling. Andreff aptly substantiates major differences between Kornai's version of disequilibrium modelling from standard ones (Barro-Grossman), inspired by Keynesian notion of aggregate demand. Most former 'planometricians' (such as Malinvaud) adopted the standard version. In Economics of Shortage, Kornai (1980) espoused an institutionalist approach that provided a basis for his recommendations regarding post-communist transformations into market economies. Andreff also shows that Kornai's recommended policy had a Hayekian flavor, in particular his support for an organic development of a privately owned sector within a gradualist process rather than mainstream-supported overnight privatization ('shock therapy'). Finally, the paper relies on Kornai's recent analysis of capitalism as a surplus economy, demonstrating the continuity of his nonmainstream views of disequilibrium over five decades.

Boettke and Candela examine Kornai's contributions to political economy through the theoretical lens of epistemic institutionalism. They raise a fundamental question on which their paper is built: what is the relationship between central planning, pervasive shortages, and soft budget constraints under socialism? They explore the evolution of János Kornai's work on the operation of realized socialist experiences in light of that question. They argue that the pervasiveness of shortages and soft budget constraints 
under 'actually existing' socialism are the effects of the lack of residual claimancy among state-owned firms, and not its cause. To put it differently, the dysfunctions of socialist economies do not stem from a misalignment of incentives in enforcing hard budget constraints and eliminating shortages. Rather, soft budget constraints are a consequence of competition between firms in a non-profit setting. Both shortages and soft budget constraints are manifestations of an excess demand for goods, the former associated with consumer goods and the latter with productive inputs. Rather than consumers and producers coordinating with one another through market prices, consumers and producers are resorting to other means of competition available to them, the soft budget constraint. Softening budget constraints emerge as means of monetizing de facto control of goods and services in the form of bribes from consumers in underground markets. The paper locates Kornai's contribution within the broad intellectual traditions of property rights economics, law and economics, public choice economics, and market process economics.

The second group of papers contains seven contributions to two fields. The first one is soft budget constraints and disruptive innovation. Three papers are devoted to the application of that concept to analyzing land reforms in Kenya, the pollution issue in China, and disruptive innovation in socialist and capitalist systems.

Leeson et al. (2020) mobilize soft budget constraints to explain dysfunctional land reforms in the developing world. According to the authors, international development organizations such as the World Bank provide support for land privatization to developingcountry governments, softening their budget constraints. The original point in the paper is to discuss the conditions under which privatization destroys wealth instead of creating it. In fact, privatization is not a free lunch; sometimes the social cost of private land rights exceeds their social benefits. Extending private property rights in such situations by subsidizing the cost externally may incentivize a government to extend private ownership rights to deliver benefits to the public sector. Leeson et al. illustrate that point by examining Kenya's land reform program. They highlight two closely related conditions that motivate a developing-country government, such as Kenya's, to pursue land privatization even when its social value is negative: (1) When the international development organizations subsidize the government's cost of privatizing land, softening its budget constraint with respect to land reform. (2) Given that subsidy, government actors benefit personally from privatizing land. The paper concludes that when the social value of land privatization is negative, softer budget constraints for land reform retard development.

Maurel and Pernet (2020) apply the concept of soft budget constraints in their econometric analysis of the effectiveness of Chinese environmental policies in cities dominated or not by state-owned enterprises (SOEs). In 2006, the Chinese central government reconsidered its environmental strategy, switching from a top-down (central government to local administration) to a bottom-up approach. Accordingly, the authors start the analysis by summarizing the main characteristics of Chinese environmental policy before 2006 and until 2010, with special emphasis on two key components of that policy. First, the authors identify the cities targeted by the central government, called the "Two Control Zone" (TCZ), 175 in number, with extremely poor environmental performances. Second, they discuss the sulfur dioxide (SO2) pollution-reduction guidelines promulgated in the central government's 11th Five-Year Plan, intended to align the motivations of governmental bureaucrats with environmental policy directives. Their econometric tests are based on rich and unique dataset assembled from the Ministry of Environmental Protection and the State Environmental Protection agency. By exploiting plausibly exogenous variations in regulatory stringency generated by environmental rules across China's provinces, they report 
evidence that pollution-intensive cities reduced their $\mathrm{SO} 2$ emissions substantially, whereas cities with strong SOE presences did not. They interpret the results as pointing to evidence of Chinese SOEs' ongoing soft budget constraints.

Inspired by Kornai's concept of soft budget constraint, Xu et al. (2020) examine why disruptive innovation has occurred almost exclusively during the last half-century in advanced capitalist economies operating under certain specific institutions, notably venture capital financed start-up companies. The study extends Kornai's (2013) theoretical framework contrasting the Schumpeterian process of creative destruction in capitalist versus socialist countries. The list of innovations, as provided by Kornai, shows that an overwhelmingly large proportion of disruptive innovations have been discovered in the United States. Xu et al. report that some of the US start-ups became leading industrial giants, such as Apple, Microsoft, Amazon, Google and Intel. However, many startups, such as DeepMind, Skype and Mobileye, eventually are acquired by larger enterprises. The latter often choose not to integrate highly uncertain R\&D projects but fund them as stand-alone small firms jointly with other financiers, i.e., by forming R\&D alliances. Thus, "idea-rich small firms" initiate disproportionate shares of innovations. That is particularly true in high-tech industries, such as in telecommunications, computers, biotechnical and pharmaceutical industries. Xu et al. examine, theoretically and empirically, why disruptive innovations mainly are discovered by outsourced R\&D alliances, many of which involve venture capital financed startups, while internal R\&D divisions of large corporates or R\&D branches of centralized socialist economies fail to do so. The underlying logic of their theory is a generalized soft-budget constraint (Kornai et al. 2003; Kornai 2013). They argue that since disruptive innovation is highly uncertain, ex post screening is critical for solving the incentive problems associated with $\mathrm{R} \& \mathrm{D}$. But such screening relies on a hard-budget constraint, namely a credible commitment to terminate failing projects. To test their theory systematically, they construct a firm-level panel dataset and investigate how strategic R\&D alliances are associated with the development of new molecular entities (NMEs) between 1998 and 2018. Their empirical findings support the theory, shedding new light on the theory of the firm in different institutional environments with implications for property rights theory.

The special issue's discussion of political economy includes four papers. The first, by Gorodnichenko and Roland (2020), uncovers a key problem in Kornai's (2016a) institutional analysis of the Chinese economic 'miracle', despite that nation's lack of freedom and democracy. The authors ask a question Kornai never considered: why did China not become a democracy? Moreover, the experience of China (but also Vietnam, Singapore or even Thailand) appears to challenge so-called modernization theory, according to which countries tend to become, or remain, democracies as they develop economically. In a more general historical perspective, while liberal democracy seemed to be 'the end of history' in the 1990s, recent developments signal the rise of 'illiberal democracy' or authoritarian tendencies. Kornai (2016a) clearly recognizes recent developments, naming it 'autocracy'. By that term, he means a type of state between democracy and dictatorship (Kornai 2015). The rise of autocratic tendencies is not limited to China, but prevails in many other ostensibly democratic countries, such as Russia, Turkey, Hungary and Poland. The authors question the validity of democratic convergence and draw our attention to a possible explanation: could modernization theories have overlooked slowmoving forces, such as culture, that may facilitate or hamper transitions to democracy? Strikingly, although culture often is considered the bedrock of many social and economic processes, the role of culture in democratization largely has been ignored until now. The authors address it and identify the source of the problem in individualist and collectivist cultures. They construct a model of revolution and transition to democracy 
under the two cultural enviornments. Their main finding is that, despite facing potentially more challenging collective action problems, countries with individualistic cultures are more likely to end up adopting democracy earlier than countries with collectivist cultures. The paper provides evidence that countries with collectivist cultures also are more likely to experience autocratic breakdowns and transitions not from autocracy to democracy but from autocracy to autocracy.

Mihályi and Szelényi (2020) also deal with China's post-socialist transition and its drift towards a non-electoral autocracy since 2013, particularly under Xi Jinping's regime. Unlike Gorodnichenko and Roland (2020), the authors do not locate the roots of dictatorship in collectivist culture, but in China's U-turn to socialism. They recall Kornai's initial position on China's political regime as a capitalist dictatorship. The Communist Party remained rhetorically communist, but in practice it "is no less friendly to private ownership and the market mechanism than Pinochet or the postwar South Korean dictators were" (Kornai 2000, p. 33). Kornai (2019a, b) recently changed his position radically, seeing present-day China, under the leadership of Xi Jinping, as increasingly returning to communist, dictatorial practices. The authors build upon Kornai's change of heart to elaborate their perspective on the specific features of China's post-socialist transition. They argue that the Chinese transition diverged radically from Europe's post-communist countries, which, as far as property rights were concerned, followed the Washington-consensus cookbook rather closely. Most of those countries privatized early and fast; priority was assigned to creating identifiable owners even if that meant transferring state property into the hands of former communist nomenklatura. China followed a dual-track approach, holding onto its large state-owned enterprises (SOEs) in many sectors, including banking and finance. Amending Kornai's criteria to determine whether a country is socialist or capitalist, the authors introduce 20 quantifiable metrics to determine whether China can be pigeonholed as capitalist or not. Based on those criteria, they conclude that present-day China seems to closely resemble the well-known, classical socialist model. While capitalist elements remain strong, in the final analysis, the country is on its way back to where it was before Deng's reforms in 1978.

Rosta and Tóth (2021) build upon Kornai's observation regarding the ascendency of autocracy in Hungary under Oban's regime, suggesting that 'illiberalism' is gaining ground in almost all post-communist countries and even in some Western democracies. In the European Union, right-wing and left-wing populist parties are increasing in strength. Meanwhile, in Central and Eastern Europe, autocracies or hybrid regimes are emerging and stabilizing. Italy and Hungary are two notable examples of those processes. Italy is the only country in Western Europe where a coalition of purely populist parties won an election, while Hungary has the most mature autocracy in the European Union. Considering those stylized facts, the paper raises a basic question: what will stop populist regimes from turning the political system into totalitarian dictatorships? In their opinion, formal institutions, regular elections, or income equality have not been sufficient safeguards for liberal democracy, at least in Hungary. They identify the value system of the society as the major safeguard. If the loyalty of the citizens shrinks when repression rises, a strongman has no chance of building up a full-fledged dictatorship. Nevertheless, if the power gain from repression exceeds the loss in loyalty, then a stable autocracy could emerge. The turning point depends on the value society assigns to liberal democracy. Using a survey methodology, the authors scrutinize the preferences of Hungarian and Italian students for liberal democracy. They find that Italian students are much more firmly on the side of human rights and less favorable to populism, left or tight. Based on their results, Rosta and Tóth claim that it is not possible to establish and maintain an autocracy in Italy because the demand for such a system is weak, even if the demand for 
populism is not, whereas establishing and maintaining an autocracy in Hungary is possible because sufficient demand for it is found amongst students' value systems.

Hénin and Insel (2021) also start by underlining Kornai's definition of 'autocracy' as a third form of political regime between democracy and dictatorship. They try to extend Kornai's analysis of a Hungarian autocratic capitalism under Oban to other countries. The authors suggest a third form of economic and political organization named 'National Authoritarian Capitalism' (NAC), a variety of crony capitalism with more or less severe forms of authoritarian social control and mobilization of a nationalist culture. The authors also see the same model unfolding in Erdogan's Turkey, which suggests a broadening of the perception of authoritarian capitalism that would not be an essentially post-communist or an Asian phenomenon.

\section{Conclusion}

The contributions to this special issue discuss Kornai's conceptual framework, its originality, practical implications, and possible extensions in understanding comparative political economics. A tour of the issue discredits a deep-rooted bias that the research on the Soviet type economy has nothing to offer since "Sovietology" died with the demise of that system. The bias has been strengthened by the idea that liberal democracy is the end of the history. The Chinese model, the so-called "illiberal democracies" and ascending authoritarian tendencies during the last two decades indicate that active state intervention in the economy, and nationalism should not be undermined. Kornai's intellectual legacy is particularly pertinent today as yesterday in exploring the causes and consequences of the political economy of a so-called 'omnipotent' state.

Acknowledgements I wholeheartedly thank Professor Shughart, the editor in chief of the Public Choice journal, for his interest and support in preparing this special issue and in publishing the exchange between Janos Kornai and Amartya Sen. I also present my thanks to peter Leeson for his constant support.

\section{References}

Andreff, W. (2020). Janos Kornai: A non-mainstream pathway from economic planning to disequilibrium economics. Public Choice. https://doi.org/10.1007/s11127-020-00813-6.

Boettke, P., \& Candela, R. (2020). Kornai, the Austrians, and the political and economic analysis of socialism. Public Choice. https://doi.org/10.1007/s11127-020-00851-0.

Commissioned editorial commentary: Exchange between Janos Kornai and Amartya Sen on Karl Marx (2021). Public Choice, Special issue In honoring Janos Kornai. https://doi.org/10.1007/ s11127-021-00892-Z

Demsetz, H. (1969). Information and efficiency: Another viewpoint. Journal of Law and Economics, 12(1), $1-22$.

Gorodnichenko, Y., \& Roland, G. (2020). Culture, institutions and democratization. Public Choice. https://doi. org/10.1007/s11127-020-00811-8.

Gregory, P. (2019). Kornai's Overcentralization and naïve empiricism. Public Choice. https://doi.org/10.1007/ s11127-019-00737-w.

Hénin, P., \& Insel, A. (2021). Hungary's U-turn in Kornai’s system paradigm perspective: A case for National Authoritarian Capitalism. Public Choice. https://doi.org/10.1007/s11127-021-00882-1.

Huang, H., \& Xu, C. (1999a). Financial institutions, financial contagion, and financial crises. Harvard University CID Working Paper No. 21, July 1999. IMF Working Papers 00/92.

Huang, H., \& Xu, C. (1999). Institutions, innovations, and growth. American Economic Review, 89(2), 438-443.

Kornai, J. (1957/1994). Overcentralization in economic administration: Critical analysis based on experience in Hungarian light industry. Oxford: Oxford University Press.

Kornai, J. (1971). Anti-equilibrium. On economic systems theory and the tasks of research. Amsterdam, Oxford, North-Holland, New York: Elsevier. 
Kornai, J. (1972). Rush versus harmonic growth. Amsterdam: North-Holland.

Kornai, J. (1980). Economics of shortage. Amsterdam: North-Holland.

Kornai, J. (1985). Contradictions and dilemmas. Cambridge: Corvina and MIT Press.

Kornai, J. (1985). Gomulka on the soft budget constraint: A reply. Economics of Planning, 19(2), 49-55.

Kornai, J. (1986). The Hungarian reform process: Visions, hopes, and reality. Journal of Economic Literature, XXIV, December. Reprinted in: Kornai Janos (1990a). Vision and reality, market and state, contradictions and dilemma revisited (pp. 99-182). New York: Routledge.

Kornai, J. (1990). Vision and reality, market and state, Contradictions and dilemmas revisited. New York: Routledge.

Kornai, J. (1990). The affinity between ownership forms and coordination mechanisms: The common experience of reform in socialist countries. Journal of Economic Perspectives, 4(3), 131-147.

Kornai, J. (1991). Market socialism revisited. Tanner Lecture (part I) delivered at Stanford University, January 18.

Kornai, J. (1992). The socialist system, the political economy of communism. Oxford: Clarendon Press.

Kornai, J. (2000). What the change of system from socialism to capitalism does and does not mean? The Journal of Economic Perspectives, 14(1), 27-42.

Kornai, J. (2006). By force of thought, irregular memoirs of an intellectual journey. London: MIT Press.

Kornai, J. (2009). Marx through the eyes of an East European intellectual. Social Research, 76(3), 965-986.

Kornai, J. (2013). Dynamism, rivalry, and the surplus economy. Oxford: Oxford University Press.

Kornai, J. (2015). Hungary's U-turn: Retreating from democracy. Journal of Democracy, 26(3), 34-48.

Kornai, J. (2016). The system paradigm revisited, Clarification and additions in the light of experiences in the post-socialist region. Acta Oeconomica, 66(4), 547-596.

Kornai, J. (2016). So what is Capital in the Twenty-First Century? Some notes on Piketty's book. Capitalism and Society, 11(1), 1-35.

Kornai, J. (2019a). Economists share blame for China's 'monstrous' turn: Western intellectuals must now seek to contain Beijing, Financial Times (p. 11).

Kornai, J. (2019). Thoughts about the Chinese market reform. Acta Oeconomica, 69(4), 485-494.

Kornai, J. (2020). 1956 in Hungary: As I saw it then and as I see it now. Public Choice. https://doi.org/10.1007/ s11127-020-00810-9.

Kornai, J., \& Lipták, T. (1965). Two-level planning. Econometrica, 33(1), 141-169.

Kornai, J., Maskin, E., \& Roland, G. (2003). Understanding the soft budget constraint. Journal of Economic Literature, XLI(4), 1095-1136.

Laffont, J. J. (1985). Fixed-price models: A survey of recent empirical work. In K. J. Arrow \& S. Honkapohja (Eds.), Frontiers of Economics (pp. 328-368). Oxford Basil: Blackwell.

Lange, O. (1958). The role of planning in socialist economy. Indian Economic Review, 4(2), 1-15.

Leeson, P. T. (2008). We're all Austrians now: János Kornai and the Austrian School of economics. Research in the History of Economic Thought and Methodology, 26, 209-219.

Leeson, P., Harris, C., \& Myers, A. (2020). Kornai goes to Kenya. Public Choice. https://doi.org/10.1007/ s11127-020-00782-w.

Maurel, M., \& Pernet, T. (2020). New evidence on the soft budget constraint: Chinese environmental policy effectiveness in SOE-dominated cities. Public Choice. https://doi.org/10.1007/s11127-020-00834-1.

Mihályi, P., \& Szelényi, I. (2020). Kornai on the affinity of systems: Is China today an illiberal capitalist system or a communist dictatorship? Public Choice. https://doi.org/10.1007/s11127-020-00835-0.

Rosta, M., \& Tóth, T. (2021). Is there a demand for autocracies in Europe? Comparing the attitudes of Hungarian and Italian university students to the values of liberal democracy inspirited by János Kornai. Public Choice. https://doi.org/10.1007/s11127-021-00877-y.

Sen, A. (2020). Marx after Kornai. Public Choice. https://doi.org/10.1007/s11127-020-00838-x.

Streissler, E. W. (1991). What kind of economic liberalism may we expect in Eastern Europe? East European Politics and Societies, 5(1), 195-201.

Vahabi, M. (1995). The Austro-Hungarian convergence through the writings of Janos Kornaï. Economie Appliquée, 48(4), 77-103.

Vahabi, M. (1998). The relevance of the Marshallian concept of normality in interior and in inertial dynamics as revisited by G. Shackle and J. Kornai. Cambridge Journal of Economics, 22(5), 547-573.

Vahabi, M. (2001). The soft budget constraint: A theoretical clarification. Louvain Economic Review, 67(2), $157-195$.

Vahabi, M. (2018). Janos Kornai and general equilibrium theory. Acta Oeconomica, 68(S), $29-54$.

Vahabi, M. (2019). Socialism and Kornai's revolutionary perspective. Public Choice. https://doi.org/10.1007/ s11127-019-00720-5.

Vahabi, M., Batifoulier, Ph., \& Da Silva, N. (2020). A theory of predatory welfare state and citizen welfare: The French case. Public Choice, 182(3-4), 243-271. 
Xu, C., Guo, D., Huang, H., \& Jiang, K. (2020). Disruptive innovation and R\&D ownership structures of the firm. Public Choice. https://doi.org/10.1007/s11127-020-00850-1.

Publisher's Note Springer Nature remains neutral with regard to jurisdictional claims in published maps and institutional affiliations. 